\title{
VIDEO MAKING TASK TO DECREASE ANXIETY IN THE STUDENTS' SPEAKING PERFORMANCE
}

\author{
Endang Setiyo Astuti ${ }^{1)}$, Indrawati Pusparini ${ }^{2)}$ \\ ${ }_{1)^{2}}^{2)}$ IKIP Budi Utomo \\ mynameisendang@gmail.com
}

\begin{abstract}
Anxiety is one of the factors influencing students' speaking performance in the classroom. A video making task is an alternative strategy that can decrease anxiety besides it provides a positive influence on students' self-assessment of speaking task. Hence, the objective of this study was to describe how video making task could decrease students' anxiety in speaking class. This study used a descriptive qualitative method in which the data source was the students' performance in video to require the task of procedure text presentation in speaking class. The data were collected by using observation and interview. And the result of the observation of the video showed that most of the students seemed less anxious and more relaxed in explaining the assigned materials. In the interview, the students also said that they felt more confident in presenting the task. In conlusion, the video making task could decrease students' anxiety in students' speaking performance.
\end{abstract}

Keywords: Video Making Task; Anxiety; Speaking Performance

CPendidikan Bahasa Inggris FPISH IKIP BU Malang

\section{Introduction}

Speaking skill in second or foreign language is a challenge for the learners, because to speak a foreign language such as English requires more than knowing grammar but the use of English in a real context. Hayriye (2006) states that speaking is to select appropriate words and sentences according to the proper social setting, audience, situation, and subject matter. Being a fluent speaker requires many knowledge towards the language learnt itself and its usage in the real communication.

Most activities in speaking class demand the students of English department in IKIP Budi Utomo to interact with each other directly, such as role play, conversation, individual or group presentation. However, the tudents still have problems in speaking English especially when they have to speak in front of class. Astuti (2019) investigated the factors influencing students' performance in English department in
IKIP Budi Utomo and found that one of non-linguistics factors influencing students' speaking performance was anxiety. Furthermore, she mentioned that the students tend to use bahasa Indonesia because they were less confident. The reluctance of making mistakes in using a foreign language lead them to express the ideas naturally in their daily language.

A similar study conducted by Fitriani (2015) also stated that the most dominant problem faced by the students in learning speaking was the psychological problems such as lack of self-confidence and anxiety. The subject of the study was the third semester students of English Study Program. The result showed that the psychological problems with mean percentage $20.70 \%$ which had the higher mean percentage than the linguitic problems (19.53\%).

In the studies above, one of the problems faced by the EFL students in their speaking performance is anxiety. In this study, anxiety is the state where 
students feel worried about making mistakes in speaking English. Anxiety can bring both the negative and positive effects. It means that it can motivate as well as disrupt the cognitive action such as learning.

The problems faced by the students above can be solved by some alternative activities in students' speaking tasks. Eventhough it is speaking skill which is usually done by interactive activities, the use of technology can be an alternative solution for this problem.

A study about students' speaking skill through vlog (video blog) has also been done by Rahayu (2018). The results showed that vlog can help the students in learning speaking and foster their speaking skill. Moreover, Rahayu stated that the students were very excited in learning speaking through vlog. It was more flexible and fun. Although vlog was suitable to be implemented for students at the intermediate and upper level, it could improve the students' speaking skill.

In another study, Rochelle et al (2011) found that most causes of foreign students experienced in the Philippines is anxiety. It was found that the use of appropriate strategy enables the learners to take charge of their own learning because the appropriate strategy provides the basic aid to learn other macro skills in the target language. In this case, the students may suddenly stop with nothing to say totheir the audiences. They may deal with certain feelings such as nervous, anxious, worry, shy, feeling afraid or fear of something worse happen if they are trying to speak better.

This study answers the following two questions, they are; What factors influence students' speaking performance? And how does video making task decrease anxiety on students' speaking performance?
Theoritically, this study can give benefit to know the factors that can influence students' speaking performance while practically, the result of the study can give teachers or lecturers to determine the appropriate strategy and material in teaching process.

The objectives of this study is to know what factors influence the students' speaking performance and how a video making task decreases anxiety on students' speaking performance.

\section{Research Method}

his study used the descriptive qualitative method in which it described how the video making task can decrease anxiety in students' speaking performance qualitatively. As Jackson (2008) stated that the descriptive research method is simply observing a behavior. So, the data instruments were observation and interview. The participants of this study were 25 students of Speaking class in IKIP Budi Utomo Malang.

The students were assigned to make a video of their performance on a procedure text presentation. The topic was about the home remedies; a traditional recipe for minor health condition. The students prepared the materials or ingredients for presentation at home. They, then explained by showing the steps how to make it orally. While explaining the steps, they videorecorded their action by using handphone camera.

The main source of the data was the submitted video of the students' speaking performance which was then analyzed by the the observation sheet and interview guide. The aspects observed from the students' speaking performance in the video, mainly were the non-linguistic aspects of confidence, topic familiarity, and anxiety. The videos were shown to the students in the 
classroom and given comments by the classmates and the lecturer. Informal interview was conducted to get more information about the process of making the video and the students' feeling and opinion about the task.

\section{Result and Discussion}

From the data of submitted video, it was found that most videos were good quality which meant that the videos had good pictures and sound. However, there were a few of them were not good because of the unclear pictures or sound. For this condition, the confirmation was done through the interview. It means that the students had such efforts to do their best to prepare their performance for the task.

\section{Observation}

The result of the observation regarding the non-linguistic aspects showed that most students were wellprepared. There were students who explained about the traditional recipes from their hometown, for example, the use of certain wooden plantation to cure the toothache. Some of them explained common recipes to ease the cough or sore throat that was the minor health problems they usually experienced. Only few students seemed not ready with the material of presentation and read the notes put in font of the camera. The students looked very familiar with the materials they presented. Most students were looking confident in presentation so that they were less anxious. Few students who were not well-prepared seemed less confident and tend to more anxious.

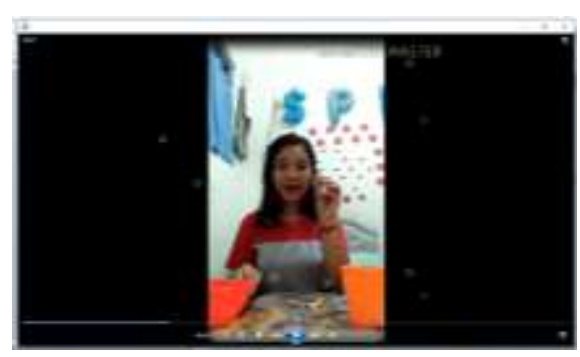

Figure 1: a student's performance video

Interview

From the interview with the students, it was known that the video making task really helped them to decrease the anxiety in their speaking performance. Most reason was that they could retake pictures of their performance several times and took the best result of it to submit. By doing this, they did self-assessment of their speaking performance. They also explained that they performed more confidently because they did not face the audience, in this case, were their own classmates and the lecturer, directly. Although very few students had problems with the topical knowledge, most students admitted that they felt comfortable with the video-making task. The result of both observation and interview in this study showed that the technology aid can be alternative strategy in process of teaching EFL. The appropriate strategy needs to apply in obtaining the objective of the learning. On the other hand, students themselves should be concerned with their own anxiety state and able to cope with the problem. So the students' skill in Speaking English will be improved in the future.

One of the audio visual media that can be used as a medium in teaching speaking is video. Many researchers believe that it is one of teaching media that helps the teaching learning process. (Kaniadewi , 2017) From the results above, it can be seen that video-making task can help the students' cope their 
speaking performance. It is in line with Rochelle et al (2011) that said that the use of appropriate strategy can motivate the learners to take charge of their own learning because it provides the basic aid to learn other skills in the target language. It is also supported by Watkins (2012) who states that video-making task develops student talk time. The more oral communication practice can decrease shyness while boosting confidence and improve fluency. Besides it improve mastery of new vocabulary and grammar. The video-making task in speaking class help shy students do their task. It is consistent with Kirkgöz (2011) whose study found that students' speaking task of video recording has significant result in helping them to overcome their anxiety.

\section{Conclusion}

One of the factors influencing the EFL students' performance in speaking skill is anxiety, a psychological state of feeling nervous when performing speaking in front of people. This study found that the video-making task give some benefits to cope this problem. In this study most of the students seemed less anxious and more relaxed in explaining the assigned materials. The students also said that they felt more confident in presenting the task. In conlusion, the video making task could decrease students' anxiety in students' speaking performance.

Beside it helps the shy students overcome their anxiety, the videomaking task can boost fluency and help the students improve their vocabulary and grammar. Because when doing the task, the students do not face the audience directly, they have more chances to retake video recording to get the best result of their performance. Hence, the video-making task can provide a positive influence on students' self-assessment of speaking task as well.

\section{References}

Astuti, E.S. \& Pusparini, I. (2019) Faktor-Faktor Yang Mempengaruhi Speaking Performance Mahasiswa Jurusan Pendidikan Bahasa Inggris. Jurnal Filsafat, Sains, Teknologi, dan Social Budaya, 25 (2), 2733.

Kaniadewi, S., et. al., (2017) Improving Students' Speaking Ability In Reporting Procedural Text By Using Video. Journal of English and Education 5 (1). pp.18-19. (online)

http://ejournal.upi.edu/index/php/ L.E/article/view/9896

Kırkgöz, Y. (2011) A Blended Learning Study On Implementing Video Recorded Speaking Tasks In Task-Based Classroom Instruction. TOJET: The Turkish Online Journal of Educational Technology - October 2011, volume 10 Issue 4

Jackson, S., L. (2008). Research Methods and Statistics: A Critical Thinking Approach. Third Edition. Belmont: Wadsworth.

Rahayu, A. S. \& Nurviyani, V. (2018) A Study Of Students' Speaking Skill Through Vlog, JOEPALLT: Journal of English Pedagogy, Linguistics, Literature, and Teaching, 6 (2)

Fitriani, D.A. et.al. (2015) A Study On

Student's English Speaking

Problems In Speaking Performance.

Jurnal Pendidikan dan

Pembelajaran Khatulistiwa, 4 (9)

Rochelle, IL et al. (2011). English Language Learning Anxiety among Foreign Language Learners in the Philippines. Philippine ESL Journal. Volume 7.

Hayriye, K. (2006). Teaching Speaking: Activities to Promote Speaking in a Second Language. Nevada: 
University of Nevada.

Watkins, J. (2012). Increasing Student Talk Time Through Vlogging. Language

Education in Asia, 3 (2). 